\title{
Strategic Design for Sustainable Tourism Management on Pangempang Beach
}

\author{
Marlon Ivanhoe Aipassa ${ }^{1, *}$, Sam Johan Emil ${ }^{2}$, Erwiantono Erwiantono ${ }^{3}$, Rochadi \\ Kristiningrum ${ }^{4}$, and Yosep Ruslim ${ }^{4}$
}

\author{
${ }^{1}$ Postgraduate, Study Program of Environmental Science Master-Mulawarman University,, Indonesia. \\ ${ }^{2}$ Department of Fisheries and Marine Affairs of East Kalimantan Province, Indonesia. \\ ${ }^{3}$ Faculty of Fisheries and Marine Science -Mulawarman University, Indonesia. \\ ${ }^{4}$ Faculty of Forestry - Mulawarman University, Indonesia, \\ *Corresponding author.Email: marlon.ivanhoe@gmail.com
}

\begin{abstract}
Strategic Design for Sustainable Tourism Management in Pangempang Beach. Pangempang Beach is an object and tourist attraction which is included in the category of developing areas and most of them have not been developed and managed professionally. The purpose of this study was to analyze land suitability, carrying capacity and effective sustainable tourism management strategies in the Pangempang Beach. The research method used is the survey method and interviews with respondents in the form of managers, tourists and the government related to a total of 100 respondents using the Slovin method while the sampling method was accidental sampling. Data analysis using land suitability methods, supporting capacity analysis and advanced tourism management criteria. The results showed that the land suitability analysis of stations I to VIII was in the very suitable category and stations IX and X were in the S2 category or quite suitable for tourism activities. The results of the analysis of the supporting capacity of the tourism area are still far below the area's carrying capacity limit for tourist visits, while overall of the 14 standard criteria for effective tourism destination management in the implementation level of sustainable tourism destination management in the coastal tourism area of Pangempang Beach.
\end{abstract}

Keywords: Carrying capacity, Coastal resources, Mangrove ecosystem, Land suitability.

\section{INTRODUCTION}

Tourism is a combination or coverage of several previous terms, namely tourism or tour. Tourism is a complex industry which includes various activities [1]. This tourism means that all tourist activities carried out by tourists are equipped with supporting facilities and infrastructure provided by tourism stakeholders. However, the most important element in a tourism development is the element of tourist attraction [2]; [3] and is closely related to travel activities [4]. Tourism development in Indonesia aims to alleviate poverty, conserve nature, environment, and resources, to cultural development, the characteristics of a nation and have close relations with other countries [5], [6] plays an important role in the economy [7], [8], [9]. Tourism revenues contribute substantially to both the current account balance and employment [10] and [11]. Tourism is the main engine for generating jobs and sustainable livelihoods [12] and [13].

The tourism destination development framework consists of the following main components attraction, accessibility, amenities, public facilities, institutions and role in supporting the implementation of tourism activities [14]. Community empowerment will be the main key to tourism development because by empowering and involving the community in tourism development, the community where tourism is developed will participate in protecting its culture and nature so that in the end sustainable tourism development is achieved and maintained [15].

Tourist destination management has a significant interest in controlling the many impacts of sustainable tourism. Destination management requires the integration of different planning tools, approaches and concepts that help shape the day-to-day management and operations of tourism activities [16]. It is necessary to increase the level of management tourism. Destination management consistent with sustainable tourism has been referred to in several ways over the years [17], sustainable tourism destination management [18] and [19]. Increasing the level of sustainable tourism management can be done by following the recommendations set by the Minister of Tourism of the Republic of Indonesia. 
Sustainable tourism development can be achieved if the level of utilization of various resources does not exceed the regeneration capacity of these resources. (1) environmental quality is maintained, (2) provides benefits for local communities and tourists; (3) tourism and the environment are maintained; (4) harmony between local communities and the environment is well established, (5) getting support from stakeholders.

Muara Badak is a sub-district located in the coastal area of Kutai Kartanegara Regency, East Kalimantan Province which has tourism potential, especially coastal tourism. One of the famous tourist attractions in this area is the beach tourism located in Tanjung Limau Village, precisely at RT 05 Dusun Pangempang. This tourist area is a land jutting into the sea which is surrounded on three sides by the sea or known as Tanjung Marangkayu which has a total length of about 13 kilometers and an area of about 91 hectares.

The coastal tourism area of Pangempang Beach, especially Panrita Lopi Beach, is one of the mainstays tourists' objects in Kutai Kartanegara Regency which has beautiful natural resources with the potential for coastal tourism. The existence of these environmental resources is supported by sufficient access and infrastructure to be a supporting factor in optimally developing Panrita Lopi Beach. However, the purpose of this statement is that with the increasing number of tourists visiting and decreasing environmental sustainability, good management is needed to maintain the sustainability of the Pangempang Beach tourist area as a beach tourism object that can continue to be utilized and maintained for the future.

Eco-friendly issues in tourism activities on Pangempang Beach can be realized with the concept of ecotourism. The development of ecotourism today is often associated with sustainable development. In this connection, the concept of sustainable development is adopted into the concept of sustainable tourism development. Sustainable tourism development is defined as a tourism development process oriented towards the preservation of resources needed for future development. Based on the points, it is necessary to have a study on the Strategic Design for sustainable tourism management in the Pangempang Beach.

\section{MATERIAL AND METHODS}

\subsection{Study Area}

This research was conducted in the tourist area of Pangempang Beach, Muara Badak District, Kutai Kartanegara Regency, East Kalimantan Province. The following is a map of the research location located in the tourist area of Pangempang Beach, Tanjung Limau Village.
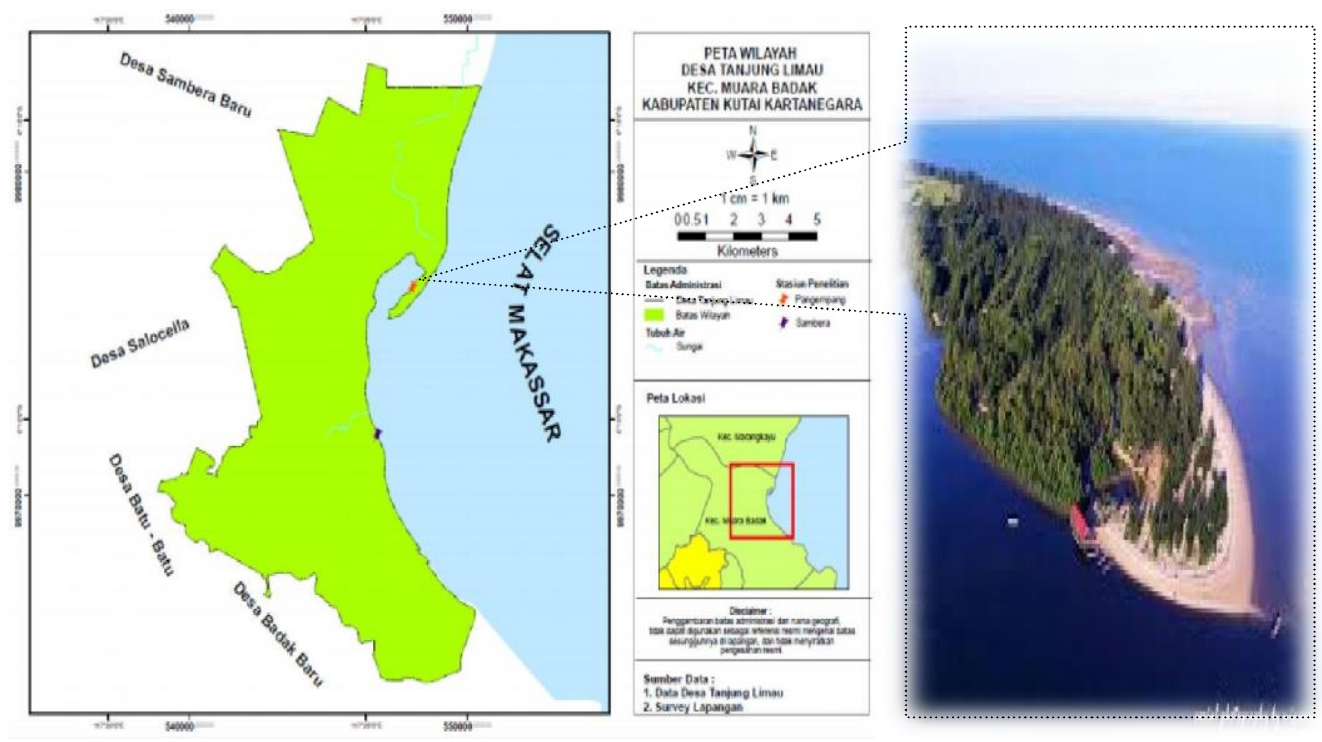

Figure 1 Research location 


\subsection{Procedures}

The data collection method is using a survey method to collect primary data and secondary data. Primary data collection uses a questionnaire related to social, economic, and field observation data for tourist visitors. Meanwhile, secondary data comes from literature studies, books on previous research reports, books related to this research and information from interviews with several sources. Determination of the number of samples using the slovin method as many as 100 respondents and taking the data by accidental sampling.

\subsection{Data Analysis}

\subsubsection{Land suitability analysis.}

The tourism activities to be developed should be adjusted to the potential resources and their allotments. Every tourism activity has resource and environmental requirements that are suitable for the tourism object to be developed. The formula used for the suitability of coastal tourism and marine tourism is [20]:

$\mathrm{TCI}=(\Sigma \mathrm{Ni} / \mathrm{Nmaks}) \times 100 \%$

where:

TCI = Tourism Conformity Index.

$\mathrm{N} \quad=$ The value of the I parameter (weight $\mathrm{x}$ score)

Nmax: = Maximum value of travel category.

The determination of suitability is based on the multiplication of the score and weight obtained from each parameter. The suitability of the area is seen from the percentage level of suitability obtained by the sum of the values of all parameters. Beach tourism consists of two categories, namely the category of recreation and mangrove tourism. The suitability of beach tourism in the recreation category considers 10 parameters with 4 classification ratings. The parameters of the suitability of beach tourism in the recreation category include water depth, beach type, beach width, water base material, current velocity, beach slope, coastal land cover, hazardous biota, and freshwater availability.

\subsubsection{Carrying Capacity Analysis}

Carrying capacity analysis is aimed at developing marine tourism by utilizing the potential resources of the coast, beaches, and small islands in a sustainable manner. Considering that the development of marine tourism is not mass tourism, easily damaged and space for visitors is very limited, it is necessary to determine the carrying capacity of the area. The assessment of the carrying capacity area (ACC) of ecotourism refers to the method introduced by [20], which uses the concept of Regional Supporting Capacity (RSC) approach. ACC is the maximum number of visitors who can physically be accommodated in the area provided at a certain time without causing disturbance to nature and humans. The calculation of RSC in the form of a formula is as follows [20]:

$$
\mathrm{ACC}=K x \frac{L_{p}}{L_{t}} x \frac{W_{t}}{W_{p}}
$$

where:

ACC = Area Carrying Capacity (Person per hour)

$\mathrm{K}=$ = Potential ecological visitors per unit area (Person).

Lp = Area or length of area that can be utilized (M2 or M)

Lt = Unit area for a certain Lp-P category (M2 or M).

$\mathrm{Wt}=$ Time provided by the region for tourism activities in one day (Hours)

Wp = Time spent by visitors for any activity (hours)

The ecological potential of visitors is determined by the condition of the resources and the types of activities to be developed in the form of beach recreation, swimming and boating with a unit area of $50 \mathrm{~m}$, where 1 person can reach $50 \mathrm{~m}$. While the time needed for each activity is 2 hours each with a total working time of around 10 hours in one day ( $7 \mathrm{am}-5 \mathrm{pm})$.

\subsubsection{Criteria for Sustainable Tourism Management}

In accordance with the Regulation of the Minister of Tourism of the Republic of Indonesia Number 14 of 2016 concerning Guidelines for Sustainable Tourism Destinations, effective sustainable tourism management includes the criteria as shown in the table below.

\section{RESULTS AND DISCUSSION}

Muara Badak District is one of the sub-districts located in Kutai Kartanegara Regency with an area of $939.09 \mathrm{~km}^{2}$, consisting of 13 villages with the sub-district capital located in Muara Badak Ulu Village. The village with the largest area was Saliki Village reaching $39.97 \%$ and the smallest area was Badak Mekar Village which only reached $0.62 \%$ of the total area of Muara Badak District. Muara Badak District has a mixed tide type, namely a mixed tide prevailing semidumal, which means that there are two ebbs and flows in one day, but the height and period are different. The total population in 2019 was 48,152 people, with the largest population in Badak Baru Village with the most densely populated village being Gas Alam Village and the rarest being Salo Palai Village [21]. 
Table 1. Sustainable tourism criteria

\begin{tabular}{|c|c|}
\hline Stages & Criteria \\
\hline Planning & $\begin{array}{ll}\text { - } & \text { Sustainable destination strategy } \\
\text { - } & \text { Planning settings } \\
\text { - } & \text { Sustainability standards } \\
\text { - } & \text { Destination management } \\
\text { - } & \text { Seasonization } \\
\text { - } & \text { Seal tourism management }\end{array}$ \\
\hline Management & $\begin{array}{ll}\text { - } & \text { Access for all } \\
\text { - } & \text { Property acquisition } \\
\text { - } & \text { Safety and security } \\
\text { - } & \text { Crisis and emergency } \\
\text { - } & \text { Pronagement } \\
\text { - } & \text { Promotion }\end{array}$ \\
\hline Monitoring & $\begin{array}{ll}\text { - } & \text { Monitoring } \\
\text { - } & \text { Inventory of assets and tourist } \\
\text { attractions }\end{array}$ \\
\hline Evaluation & $\begin{array}{l}\text { - } \quad \text { Climate change adaptation } \\
\text { - } \quad \text { Visitor satisfaction }\end{array}$ \\
\hline
\end{tabular}

Pangempang Beach is one of the beach tourist's attractions located in Tanjung Limau Village, RT. 05 Pangempang Hamlet, Muara Badak District, Kutai
Kartanegara Regency. This area has a total length of about $13 \mathrm{~km}^{2}$ with an area of about 91.21 hectares while the length of Pangempang Beach which is managed for temporary tourism activities is about $3.2 \mathrm{~km}$. The management of tourism activities in this area is carried out by residents or the government who have ownership in the area. The legality of this area can be traded based on information from the Muara Badak District and included the Kutai Kartanegara Regent's Decree regarding the determination of the boundaries of the Tanjung Limau Village area. The decree states that Pangempang Beach is an integrated land or part of Tanjung Limau Village, the name is Tanjung Marangkayu with 18 beach managers located in the Pangempang Beach tourist area and only 7 managers who are considered active in their tourism activities are Jingga Beach, Pasir Beach Putih, Pelangi Beach, Blue Beach, Mutiara Indah Beach, Panrita Lopi Beach and Kurma Beach. With the existence of tourism activities and an increase in the number of tourist visits, it encourages beach managers to make improvements to the land they have so that later they can receive visits from tourists.

Coastal management activities in this area have been running for more than 8 years and until now the management is still self-managed by residents. The status of land ownership and permanent or semi-permanent buildings is fully owned by the private beach manager so that in this case the beach manager has no obligation to pay taxes related to tourism activities. The following picture shows several beaches in the Pangempang Beach
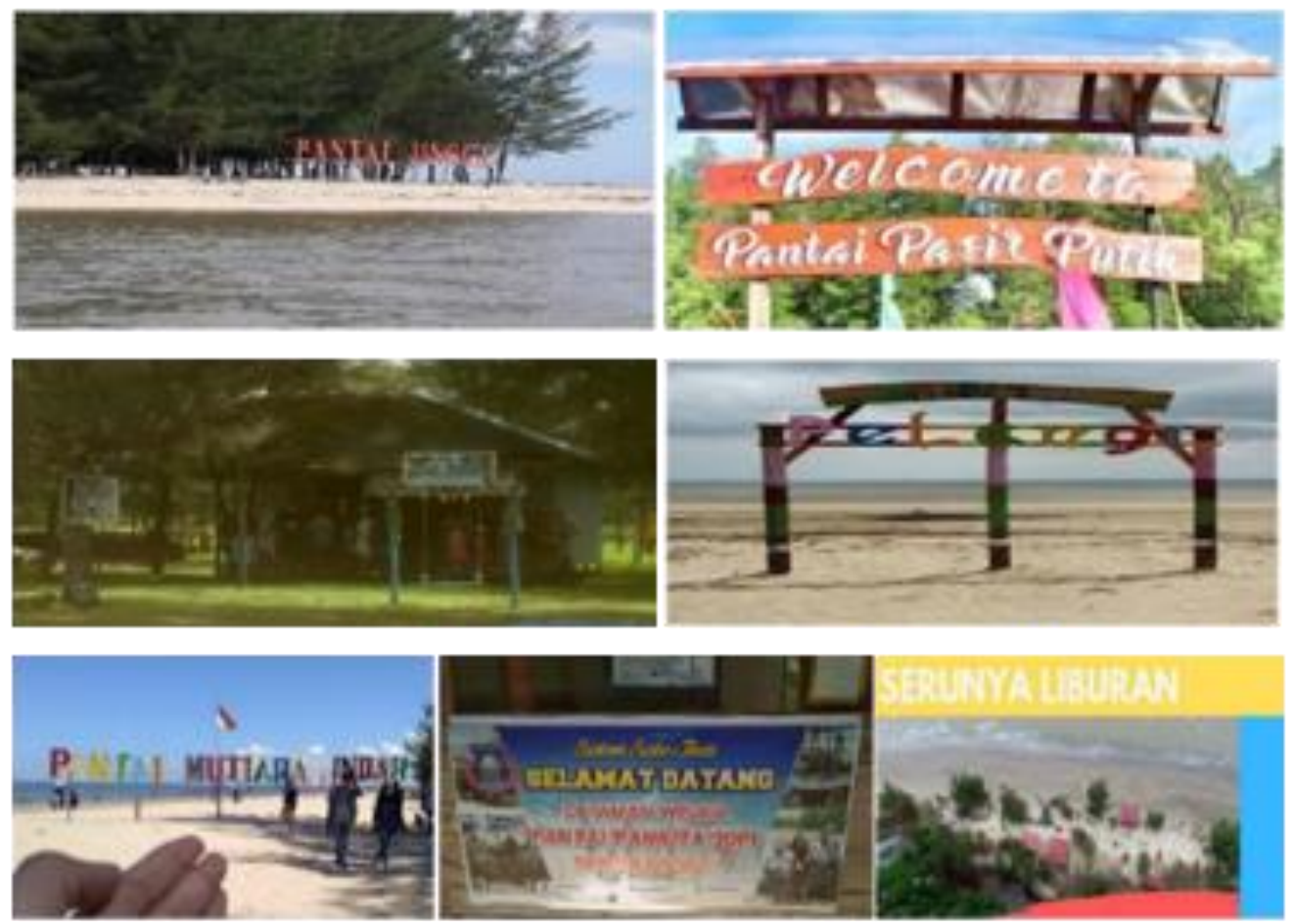

Figure 2 Some clues that indicate the names of Pangempang 


\subsection{Panrita Lopi Beach Management}

In the tourism sector, scenario planning has been proposed by several researchers [21], [22] and [23] as a systematic approach to creating and testing possible future scenarios in an uncertain environment. Scenario planning is based on two stages: firstly, developing and implementing simulations to anticipate possible futures, and secondly assessing the implications of managerial skills and decision-making for evaluating these futures [24].

Based on the Law of the Republic of Indonesia No.10 of 2009, tourist attraction is anything that has uniqueness, beauty, and value in the form of a variety of natural, cultural, and man-made wealth that is the target or purpose of tourist visits. According to [25], there are 6 elements of tourist attraction, namely originality and natural beauty (authenticity and natural beauty); (2) Variative; (3). Scarcity (rarity/limited); (4). Uniqueness; (5). Totally (wholeness) and 6. Wholesomeness (useful). Meanwhile, according to [26] through attractions or objects, accessibility, facilities, tour packages, additional activities and services can be used as a tourism development strategy. Meanwhile, the object of tourist attraction is described by [27] as a formation and facilities that are interconnected and become the reason / cause for tourists to visit a certain area or place. The tourism capital or tourism source has the potential to be developed into a tourist attraction. Attractions are also called tourist objects and attractions which are a driving factor for tourists to travel to tourist destinations. From several beach managers in the Pangempang Beach, Panrita Lopi Beach is quite prominent in terms of service, marketing, facilities, and infrastructure as well as the natural beauty of the location. This is proven by the number of tourist visits to this beach which is relatively stable and increases when compared to tourist visits on other beaches in the Pangempang Beach. This beach is in Lat S -0012 "Long E 117025" or 0012'37"S 117026'06 "E with the mangrove species that dominate this area, the type of Avicenna $s p$, white sand and pine trees that decorate this beach area. Besides the beauty above, there are also primate's native to the island of Borneo, namely is Bekantan (Nasalis lavartus) that are in the mangrove trees and often appear around 7 am and 5 pm to look for food.

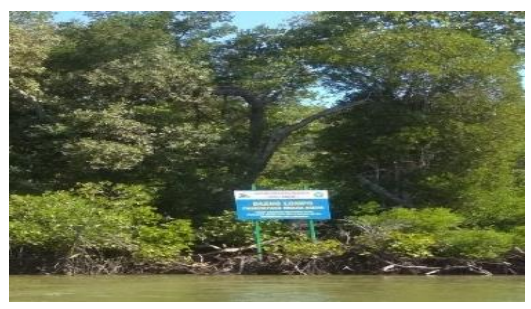

a. Mangrove Forest

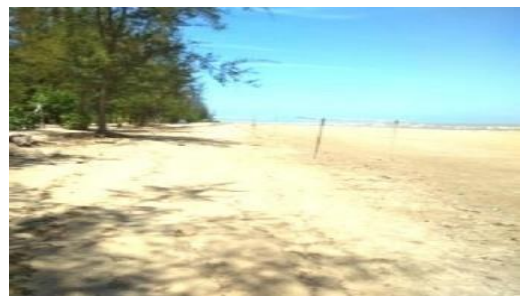

d. White sand

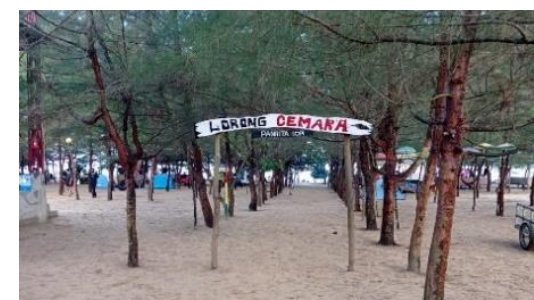

b. Fir alley

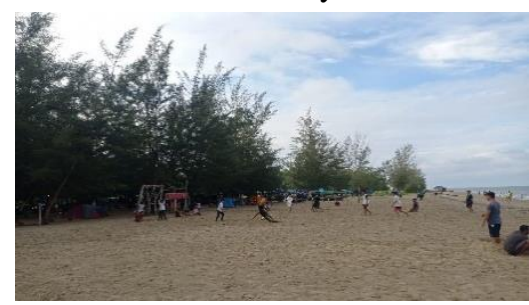

e. Playground area

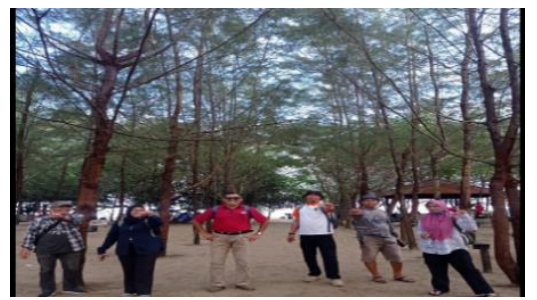

c. Pine alleywasy

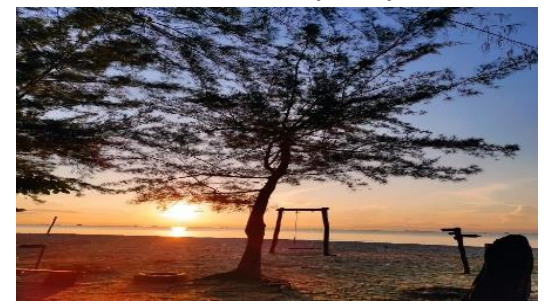

f. Panoramic sunset

Figure 3 The appearance of mangroves, white sand and pine alleyways which are part of the beauty of Panrita Lopi Beach

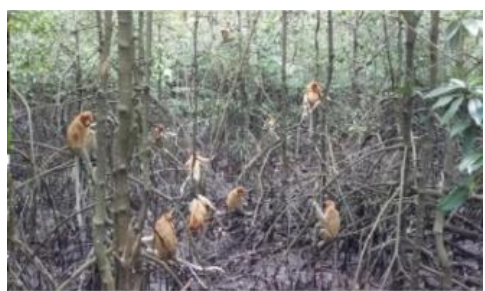

a. Bekantan (Nasalis lavartus)

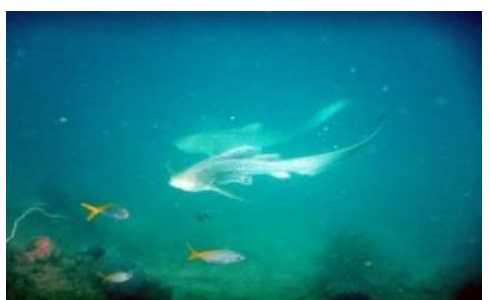

b. Marine life

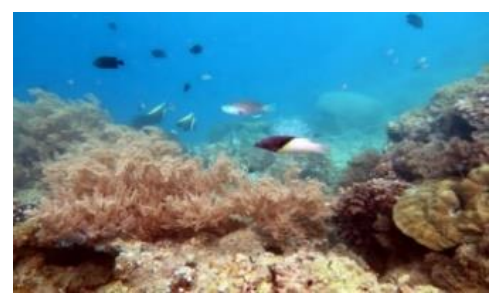

c. Coral reefs

Figure 4 The appearance of Bekantan in the mangrove trees, coral reefs, and marine life in Pangempang Beach 


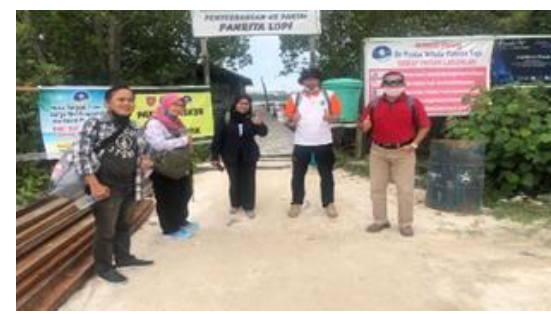

a. Crossing entrance

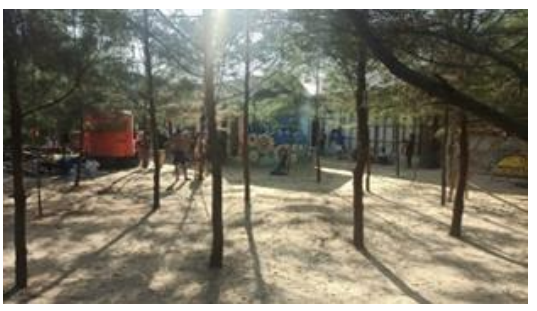

d. Toilet and bathroom

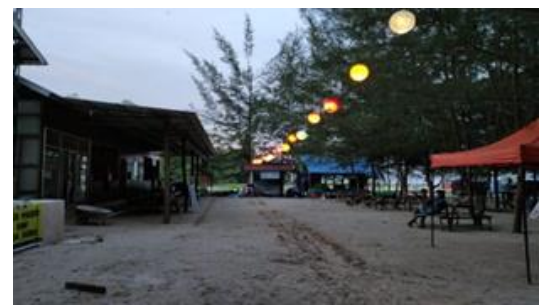

g. Food stalls

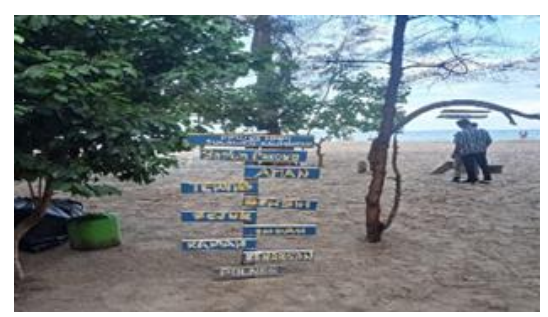

j. Motto of Panrita beach

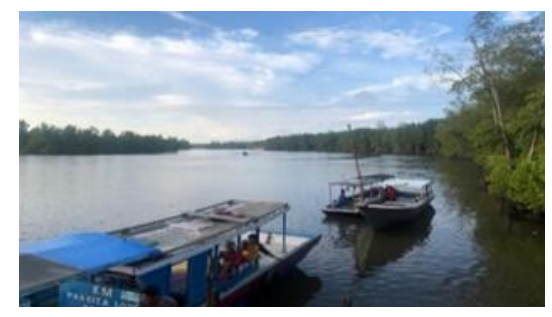

b. Cruise ship

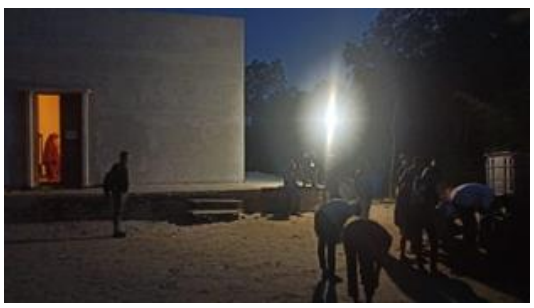

e. Prayer room

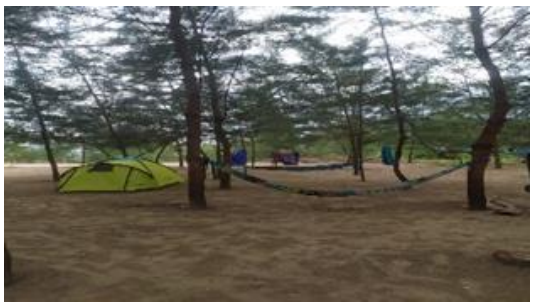

h. Camping ground

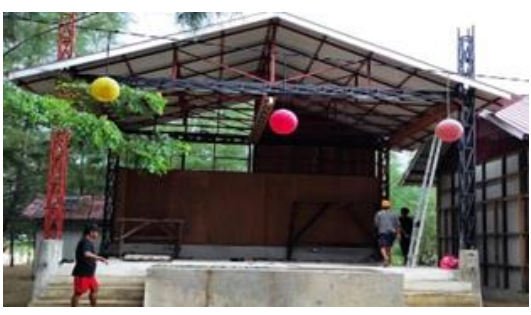

k. Entertaimant stage

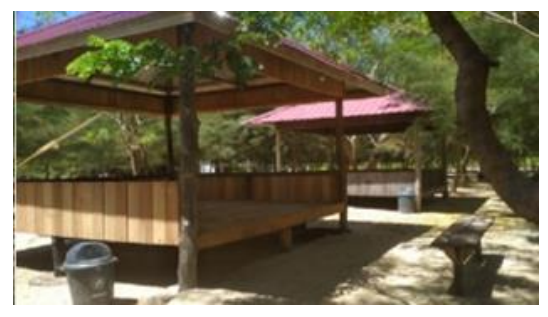

c. Gazebo and garbage bin

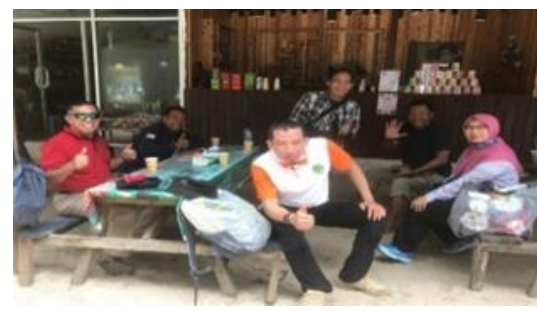

f. Coffe shop

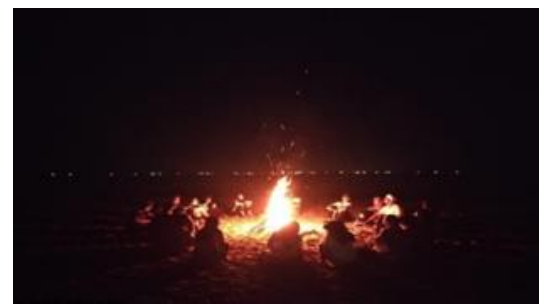

i. Camp fire

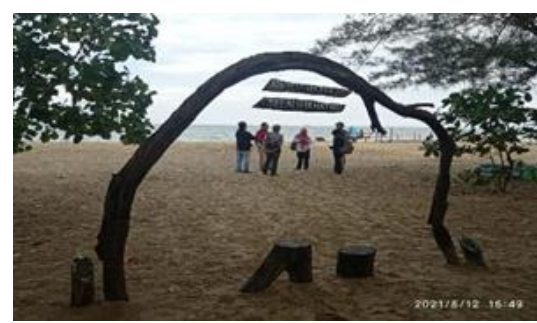

1. Boot foto

Figure 5 Appearance of existing facilities on Panrita Lopi Beach

Another attraction of the Pangempang Beach is the presence of hawksbill turtles (Eretmochelys imbricate) which can sometimes be found on the coast and and there are also marine life also coral reefs that we can see when we dive to a depth of 4-40 metres. The presence of marine life and coral reefs indicates that the level of water fertility is quite good and the food source for ecosystem. [28] stated that the mangrove forests of the Mahakam Delta to the Muara Badak sub-district are naturally the habitat for the distribution of wild animals (mammals and birds), including proboscis monkeys as a typical species of Kalimantan Island. Which are overgrown with pedadas (Sonneratia alba), because these animals eat the leaves/flowers and fruit of the pedada (Scylla spp), Crab (Polymesoda erosa), Lizard (Veranus salva) tor) and Snake (Fordonia leucobalia). This is in line with According to [29] and [30], mangrove ecosystems have diversity of mammals, reptiles, fish, and invertebrates so that it can be a special attraction for the development of mangrove ecosystem tourism in the area.

[31] assesses that the results of the analysis carried out in the Pangempang Beach area have the potential for marine tourism with a background of mangrove forests, beaches and holding a coastal cultural festival featuring regional dances and tribes in Muara Badak District. [32], shows that the condition of coastal resources (mangroves and beaches): the types of mangrove communities in Pangempang Beach consist of A. alba, N. fruticans, $R$. apiculata and $S$. alba, namely $R$. apiculata species dominating the area. Meanwhile, according to [28] stated that the mangrove ecosystem in Tanjung Limau Village, Muara Badak District, found 5 types, namely $R$. apiculata, A. alba, N. fruticans, C. tagal and S. alba. Meanwhile, [33] stated that Mentawir Village, which is the Balikpapan Bay area, has 12 types of mangrove plants which are dominated by $R$. apiculata, $R$. mucronata and 
Bruguiera sp.This means that $R$. apiculata dominates the mangrove ecosystem in the province of East Kalimantan.

In addition to the attractiveness of flora and fauna, tourist facilities are also part of the attraction of tourist recreation spots. As a beach tourism object that is widely known by the people of Muara Badak District and other surrounding areas, Panrita Lopi Beach has 13 types of adequate infrastructure and facilities as beach tourism spots and is well organized. The facilities or facilities in question are the existence of 2 large parking lots, 2 ticket booth units, 9 crossing units, 1 crossing bridge unit with a length of 73 meters, 2 units of anchoring and berth jetty,

Tourist visits are one of the sustainability factors of the development of a tourist attraction. The tourism sector will be the main driver of the 21 st century world economy and become one of the globalizing industries [5]. The beginning of the management of Panrita Lopi Beach began in October 2016 and in February 2017 it started receiving visitors. However, data on tourist visits from June 2019 to August 2020 were 47,740 people with an average daily visit of 102 people and an average of 3,182 visitors per month with the highest number of visitors in August 2020 as many as 11,226 people and in April 2020. without any visitors because in that month following instructions from the local government to be temporarily closed due to the outbreak of the Covid-19. While the total number of visitors to the Pangempang Beach in 2018 reached 96,593 people and in 2019 it reached 126,903 people.
19 toilets and 3 units bathroom general; 1 unit of basic food stalls; 3 units of food stalls; 1 unit of prayer room; 3 gazebo units with $3 \times 2 \mathrm{~m}$ size, 3 gazebo units with $4 \times 3 \mathrm{~m}$ size and 1 gazebo unit with $4 \times 4 \mathrm{~m}$ size; 1 entertainment stage unit; and cleaning facilities in each facility. The following is a description of one of the gazebo facilities in the Panrita Lopi Beach area. Apart from this, tourists also play the waves on the beach. The tides have an influence on activities carried out at sea, namely shipping activities, fishing activities, loading, and unloading of ships and surfing activities, because tidal events do not occur at the same time, therefore it is necessary to predict tides [34].

\subsection{Land Suitability Analysis}

The land suitability analysis of Pangempang Beach tourism area is specifically for beach recreational tourism activities in accordance with existing activities at the beach location. Observation and sampling for the matrix of land suitability for tourism on the beach is divided into 10 stations or areas, where each area is 200 meters long of the coastline so that the overall length of the station reaches 1800 meters or 1.8 kilometers. Determination of observation stations and sampling is carried out with the benchmark position of Panrita Lopi Beach at station V and station VI. Stations I, II, III, IV and V start on the right or south of Panrita Lopi Beach while stations VI, VII, VIII, IX and $X$ are on the right or north side of Panrita Lopi Beach. The following is a map of 10 observation stations in the Pangempang Beach.

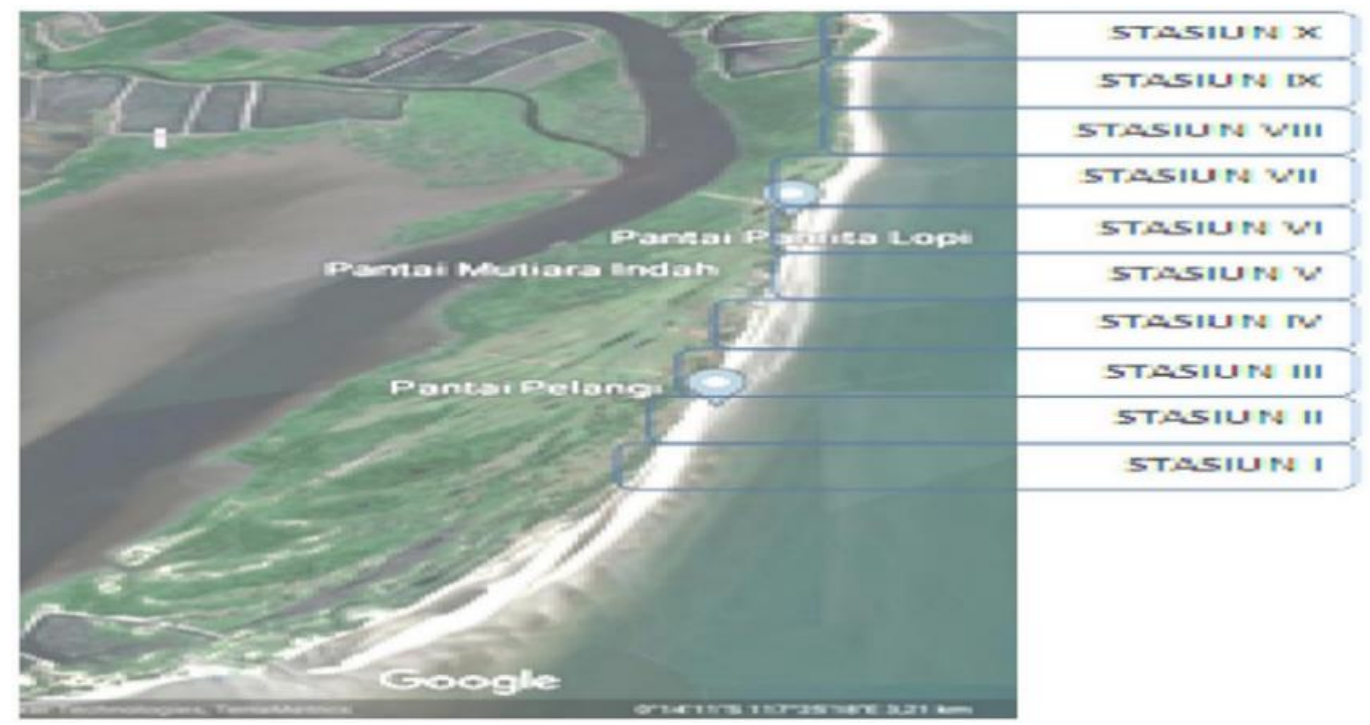

Figure 6 Map of the location of the observation station on Pangempang Beach 
Table 2. Category of observation results at 10 stations.

\begin{tabular}{|c|c|c|c|c|c|c|c|c|c|c|c|}
\hline \multirow{2}{*}{ No } & \multirow{2}{*}{ Parameter } & \multicolumn{10}{|c|}{ Result Category Observation of Land Suitability of Each Station } \\
\hline & & 1 & ॥ & III & IV & V & VI & VII & VIII & IX & $x$ \\
\hline 1. & Depth of Water (m) & S1 & S1 & S1 & S1 & S1 & S1 & S1 & S1 & S1 & S1 \\
\hline 2. & Dangerous Biota & S2 & S2 & S2 & S2 & S2 & S2 & S2 & S2 & S2 & S2 \\
\hline 3. & Beach Width (m) & S1 & S1 & S1 & S1 & S1 & S1 & S1 & S1 & S1 & S1 \\
\hline 4. & Availability of Fresh Water & S1 & S1 & S1 & S1 & S1 & S1 & S1 & S1 & S2 & S2 \\
\hline 5. & Basic Water Material & S1 & S1 & S3 & S3 & S1 & S1 & S2 & S2 & S3 & S3 \\
\hline 6. & Flow Velocity $\left(\mathrm{m} \mathrm{sec}^{-1}\right)$ & S2 & $\mathrm{S} 2$ & S2 & S1 & S2 & S2 & S1 & S1 & S1 & S2 \\
\hline 7. & Beach Type & S1 & S1 & S1 & S1 & S1 & S1 & S2 & S2 & $\mathrm{S} 2$ & S2 \\
\hline 8. & Brightness (m) & $\mathrm{N}$ & $\mathrm{N}$ & $\mathrm{N}$ & $\mathrm{N}$ & $\mathrm{N}$ & $\mathrm{N}$ & $\mathrm{N}$ & $\mathrm{N}$ & $\mathrm{N}$ & $\mathrm{N}$ \\
\hline 9. & Slope $\left(^{0}\right)$ & S1 & S1 & S2 & S1 & S1 & S1 & S1 & S1 & S1 & S1 \\
\hline 10. & Land Closure & S1 & S1 & S2 & S1 & S1 & S1 & S2 & S2 & S3 & S3 \\
\hline & Scoring & 146 & 146 & 132 & 142 & 146 & 146 & 139 & 139 & 127 & 123 \\
\hline
\end{tabular}

Information: S1 (very suitable, with a value of 80\%-100\%/131-164); S2 (quite appropriate, with a value of 60\%-<80\%/98-130), S3 (according to the conditions, with a value of $35 \%-<60 \% / 57-97$ ) and $\mathrm{N}$ (not suitable, with a value of $<35 \% /<56$ ).

In general, Pangempang Beach is very suitable for beach tourism activities. This is shown by the analysis of the suitability of several parameters for coastal tourism activities, including depth, beach type, beach width, availability of fresh water, water base material, current velocity, slope, brightness, coastal land cover and hazardous biota. The categories of observations at 10 observation stations can be seen in Table 2

By scoring stations I, II, III, IV, V, VI, VII, and VIII are categorized as S1 or very suitable and stations IX and $\mathrm{X}$ are categorized as $\mathrm{S} 2$ or quite suitable for tourism activities. In general, playing sand, beach sports, walking along the beach or using an ATV can be done at each station because the type of beach for each station is white sand, not mud, but station I is less attractive to visitors because of the poor level of cleanliness. This is because there is no management of the beach area at Station I by the community so that the cleanliness of the beach is not maintained due to rubbish or dirt being swept away by the waves. For visitors who want to spend the night and do camping activities, it should be done at stations II, IV, $\mathrm{V}$ and VI because each station has beach management such as Pelangi Beach, Mutiara Indah Beach, Bala Nipah Beach and Panrita Lopi Beach. The basic materials at the observation station have similarities and differences. Station I, II, V and VI have sandy water base material. Station III, IV, IX and X have basic muddy sand waters, while stations VII and VIII have sandy coral reefs. Surfing, snorkelling, swimming in the sea and boating and banana boat activities should be done at stations that have sandy water base material such as stations I, II, V and VI.

\subsection{Analysis of Carrying Capacity Pangempang Beach}

The carrying capacity of the Pangempang beach tourism area at 10 observation stations can be seen in the Table 3 .

Table 3. The carrying capacity of Pangempang Beach tourism area.

\begin{tabular}{|c|l|c|}
\hline No & \multicolumn{1}{|c|}{ Type of activity } & $\begin{array}{c}\text { Area Carrying } \\
\text { Capacity (people } \\
\text { per day) }\end{array}$ \\
\hline 1. & Down the beach on foot & 90 \\
\hline 2. & Down the beach with an ATV & 180 \\
\hline 3. & Playing with sand & 180 \\
\hline 4. & Beach sports & 90 \\
\hline 5. & Camping & 42 \\
\hline 6. & Play sea water / waves & 48 \\
\hline 7. & Swimming & 48 \\
\hline 8. & Snorkeling & 48 \\
\hline 9. & Boating & 180 \\
\hline & & 906 \\
\hline
\end{tabular}


Based on the data above, it can be explained that the types of activities along the beach with APV vehicles, playing sand and boating have an area carrying capacity of 180 people per day each. Meanwhile, along the beach and doing beach sports, each area has a carrying capacity of 180 people per day. Meanwhile, the types of activities that have an area carrying capacity of 48 people per day are in the form of playing sea water/waves, swimming and snorkelling. This is supported by the type of tide in the village of Tanjung coastal Pangempang, which is included in the type (Mixed Tide Prevailing Semi Diurnal), where the tides that occur are two times the tide and two times the tide is almost the same high [22]. Camping has the smallest area carrying capacity, which is 42 people per day. The carrying capacity of the Pangempang Beach area has similar potentials to the Wediombo beach of Gunung Kidul Regency. This is in accordance with the statement [25], where the tourism potential is in the form of natural tourism, sunset panoramas, snorkelling, surfing, lagoons, fishing, camping ground, and photo spots.

The number of visitors to Pangempang Beach tourist attractions according to the Central Bureau of Statistics Kutai Kartanegara Regency in 2019 reached 126,903 people, so that the average visit per day reached 347 people. Meanwhile, the number of tourist visits to Panrita Lopi Beach itself in 2020 from January to August reached 35,454 people, so that the average daily visit reached 97 people. Thus, when compared with the calculation of the carrying capacity of the area which produces 906 people per day, the carrying capacity of the area for tourism activities in the tourist area of Pangempang Beach or at Panrita Lopi Beach itself is still far below the area's carrying capacity limit for tourist visits.

\subsection{Management of Sustainable Tourism Destinations}

Sustainable tourism is an alternative form of tourism that exists based on several principles, namely minimizing the impact of tourism activities on the environment to achieve ecological sustainability, maintaining and increasing conservation status by returning a portion of the income to protected areas; minimize the negative impact of tourism activities on local communities in order to achieve social sustainability; and minimize the negative impact of tourism activities on the culture of local communities in an orderly manner to achieve cultural sustainability [35].

Community-based sustainable tourism requires efforts to diversify tourist attractions that are oriented towards improving community welfare, preserving cultural arts, and developing eco-friendly tourism [36]. There are various tools to promote sustainable tourism management at various levels each with a different focus. Sustainability tools are essential for destination management. The ten main groupings of tools include area protection, industry regulation, visitor management techniques, environmental impact analysis, supporting capacity calculations, consultation and participation techniques, codes of conduct, sustainability indicators, carbon budget analysis and fair trade in tourism [37] and the tourism development strategy is to develop ecotourism, promote the attractiveness of ecotourism, develop educational tourism education, and promote diversity of flora, fauna, culture, and traditional customs [30].

Effective management of sustainable tourism destinations includes the stages of planning, management, monitoring and evaluation. Sustainable tourism development requires a planning and management process that brings together the interests and concerns of various stakeholder groups in a capable and strategic manner in a sustainable manner [38]. In observations by the author of the Objects and Attractions of Pangempang Beach, there are 6 out of 14 criteria that are applied in efforts to manage sustainable tourism destinations, namely sustainable destination strategies, seasonal tourism management, promotion, property acquisition, monitoring and visitor satisfaction. The stages of the criteria for sustainable tourism include planning, management, monitoring and evaluation. This is in line with [39] which states that sustainable tourism is a sign that is given to a place that shows progress, thus respecting the work done by managers. This system is a practical tool for linking evaluation with planning decisions and destination management.

At the planning stage with the criteria for a sustainable destination strategy, there are several documents that serve as supporting evidence that the intended destination received attention in the form of area legitimacy from related parties, in this case the East Kalimantan Provincial Government through the Tourism Office and the Marine and Fisheries Service. Sustainable regional development is an effective collaboration between the use of existing resources, the community, and the government. In this case, the government as a regulator plays a strategic role in striving for community empowerment through optimization of local resources, while managers and policy makers play a role in sustainable tourism development [37], [40] and [41].

The District Government of Muara Badak and Tanjung Limau Village also participated through an assistance program aimed at improving the quality of facilities and infrastructure, and human resources in the tourism sector. At the management stage with the criteria for seasonal tourism management, the manager of Panrita Lopi Beach has a tourism calendar throughout the year. In terms of management stages with promotional criteria, the manager of Panrita Lopi Beach has collaborated with government and private agencies and carried out promotions via electronic media and social media with the aim of increasing the quantity of visitors and the 
quality of management of these tourist attractions. The existence of rules regarding land ownership indicates that the property acquisition criteria have been applied in the coastal tourism area of Pangempang Beach. This is in line with [5] and [42] that the development of sustainable marine tourism can be done by collaborating with the government, promoting, improving the quality of human resources to compete in the development of tourism objects. And according to [43] state that infrastructure, design and product rural tourism packages, skills development programs for stakeholders, and special marketing campaigns are very important in tourism development.

At the monitoring stage with monitoring criteria, the manager of Panrita Lopi Beach internally reports and coordinates between managers ranging from parking lot managers, ticket administrators, crossing boat administrators, cleaning managers, tourism equipment administrators, administrators of infrastructure, electricity and water network administrators, and manager of the food stall led directly by the owner of the Panrita Lopi Beach land. The next stage is evaluation. Evaluation is the last stage of implementing sustainable tourism destination management. In this case the evaluation stage has criteria, namely visitor satisfaction which is equipped with visit data and tourist satisfaction data where visitor satisfaction with attractions, facilities and services, accessibility, image of tourist objects and costs or prices reaches $96 \%$ and tourist dissatisfaction includes less toilet facilities. adequate, inadequate food stall facilities, inadequate health facilities, inadequate road directions along the road to tourist objects, public transportation facilities that are not available along the road to tourist objects, inadequate communication networks, rarely held supporting attractions, prices food and expensive tourist equipment rental prices reach $4 \%$. This is in line with research conducted by [44] that efforts to develop tourism have not been optimal in human resource management, there is still need for training, there is no operational transportation, there is a need for additional supporting facilities, tourism objects along the way. Even though it should be in the development of sustainable tourism according to [45], providing facilities and infrastructure for tourist objects, building, and holding tourism accessibility as one of the strategies for developing tourist objects.

Overall, of the 14 standard criteria for effective tourism destination management, there are 6 criteria that currently apply in general in the coastal tourist areas of Pangempang Beach and especially on Panrita Lopi Beach. The criteria referred to are sustainable destination strategies, seasonal tourism management, promotion, monitoring and visitor satisfaction. The criteria that have not been implemented include planning arrangements, sustainability standards, destination management organizations, access for all, property acquisition, safety and security, crisis and emergency management, asset inventory and tourist attractions and climate change adaptation.

The 6 criteria that can be implemented include sustainable destination strategies, seasonal tourism management, property safety, promotion, monitoring and visitor satisfaction and this is in line with [2] that one of the strategies for developing marine tourism is promotion through print media. and online and infrastructure development. Meanwhile, the 8 criteria that have not been implemented are planning for sustainability standards, destination management organizations, access to all acquisitions, crisis and emergency management, inventory of assessments, tourist attractions, adaptation to climate change. Sustainable tourism responds to the needs of tourists and receiving areas to protect and enhance resources for future generations. the aim is to integrate all resources to meet economic, social, and aesthetic needs without compromising the preservation of cultural integrity, important ecological processes, biodiversity, and the environment [35].

There are 3 strategies for the management and development of mangrove ecotourism in Tanjung Limau Village [28], namely: first to make proposals to the private sector and government in increasing efforts to manage and develop mangrove ecotourism through capital assistance and improvement of tourism facilities and infrastructure in Tanjung Limau Village, secondly to increase / encourage government participation in helping communities to manage and develop mangrove ecotourism and thirdly coordination and cooperation between communities, NGOs, private sector and government in managing and developing mangrove ecotourism, another way of developing tourism object development strategies in coastal areas by conducting empowerment, counselling in order to grow and increase public awareness of the importance of a tourism awareness community, and to coordinate with the private sector to invest, develop tourism attractions and tourist attractions, infrastructure. and facilities, community participation, institutions, environmental quality, investment opportunities, resource protection, policies and marketing are also factoring in the development of marine tourism areas [25], [46] and [45].

Based on the above explanation, it is necessary to immediately apply the criteria that have not been implemented so that the management of sustainable tourism destinations can be implemented and materialized as the standardization of Sustainable tourism destinations as stated in the Minister of Tourism Regulation No. 14 of 2016. This is in line with [47] state that sustainable tourism development requires informed participation of all relevant stakeholders, as well as strong political leadership to ensure broad participation and consensus building, realizing sustainable tourism is a sustainable process and requires constant impact monitoring, introducing prevention and or corrective 
action is required when necessary. Sustainable tourism must also maintain a level of tourist satisfaction and ensure a meaningful experience for tourists, raise their awareness of sustainability issues, and promote sustainable tourism practices among them.

\section{ACKNOWLEDGMENTS}

The authors would like to thank Mr. Daeng Lompo, and Mr. Mansur who serves as key respondent at the study sit.

\section{REFERENCES}

[1] Haraldsson HV, Olafsdóttir R. 2018. Evolution of tourism in natural destinations and dynamic sustainable thresholds over time. Sustainability $\mathbf{1 0}$.

[2] Khotimah K, Wilopo W. 2017. Cultural tourism destination development strategy (Case Study on Trowulan Site Area as Leading Cultural Tourism in Mojokerto Regency). J of Business Administration 42 56-65.

[3] Attar M, Hakim L, Yanuwiadi B. 2013. Potential analysis and strategic direction of ecotourism village development policy. J Ind Tour Dev Std 1 68-78.

[4] Jepriyus. 2017. Development efforts to develop object to guruh waterfall gemurai by the department of culture and tourism Singi Quantant district. Online J of Soc and Political Sci Faculty Students 4 $1-18$.

[5] Subagyo. 2012. Tourism development strategy in Indonesia. J Liquidity 1 153-158.

[7] Nematpour M, Khodadadi M, Rezaei N. 2021. Systematic analysis of development in Iran's tourism market in the form of future study: A new method of strategic planning. Futures 125.

[8] Amerta IMS. 2017. Community based tourism development. International Journal of Social Sciences and Humanities 1 97-107.

[9] Bahiyah CR, Sudarti. 2018. Tourism potential development strategy in Duta Beach, Probolinggo Regency. J of Eco 2 95-103.

[10] Smolović JC, Janketić S, Jaćimović D, Bučar M, Stare M. 2018. Montenegro's road to sustainable tourism growth and innovation. Sustainability (Switzerland) $\mathbf{1 0 .}$

[11] Blancas FJ, Oyola L, González, M. 2015. A European sustainable tourism labels proposal using a composite indicator. Environmental Impact Assessment Rev 54 39-54.
[12] Beg F, Irfan SS. 2015. Sustainable tourism development in India with Special Reference to Nainital-Uttarakhand. November.

[13] Tapatfeto MAK, Bessie JL, Kasim A. 2018. Tourism object development strategy in an effort to increase visits (Study on Oetune Beach Tourism Object, TTS Regency). J of Manage 6 1-20.

[14] Sunaryo B. 2013. Tourism Destination Development Policy: Concept and Application in Indonesia. Gava Media, Yogyakarta.

[15] Sutawa GK. 2012. Issues on Bali tourism development and community empowerment to support sustainable tourism development. Procedia Economics and Finance 4 413-422.

[16] Conaghan A, Hanrahan J, Mcloughlin E. 2015. The sustainable management of a tourism destination in ireland: a focus on county clare. An International Journal of Akdeniz University Tourism Faculty 3 62-87.

[17] Welford R, Ytterhus B. 2004. Sustainable development and tourism destination management: A case study of the Lillehammer region, Norway. Inter J of Sustain Dev and World Ecology 11 410 422.

[18] Jamieson, Noble. 2000. A Manual for sustainable tourism destination management. The Canadian International Development Agency. Canadian Universities.

[19] Griffin K, Flanagan S, Fitzgerald J. 2012. The Challenge of implementing a sustainable tourism assessment tool in an Urban Environment. Germany 13-14.

[20] Yulianda. 2007. Marine ecotourism as an alternative utilization of coastal resources based on conservation. Presented at the Science Seminar February 21, at the Department of Aquatic Resources Management, Institut Pertanian Bogor.

[21] Mahmudin, Suyatna I, Adnan. 2016. Tidal prediction using neural nets (backpropagation) in pantai indah kutai regency of east borneo. $J$ of Tropic Fish Sci 22 10-19.

[22] Nematpour M, Faraji A. 2020. Structural analysis of the tourism impacts in the form of future study in developing countries (case study: Iran). J of Tourism Futures 5 259-282.

[23] Postma A. 2015. Investigating scenario planning: a European tourism perspective. J of Tourism Futures $146-52$

[24] Mai T, Smith C. 2015. Addressing the threats to tourism sustainability using systems thinking: a case 
study of Cat Ba Island, Vietnam. J of Sustain Tourism 23 1504-1528.

[25] Mayasari CU. 2017. Wediombo Beach Development Strategy, Gunungkidul Regency. J of Khasanah Ilmu 8 65-71.

[26] Raharja SJ, Marbun M, Chan A. 2019. Rural tourism development strategy in Lebak Muncang, Bandung West Java. Sociohumanities 21 159-165.

[27] Hadiwijoyo. 2012. Community based rural tourism planning (a concept approach). Graha Ilmu, Yogyakarta.

[28] Ismail, Helminudin, Abdunur. 2018. Mangrove ecotourism management and development strategy in Tanjung Limau Village, Muara Badak District. Agrifor 17 281-292.

[29] Kristiningrum R, Lahjie AM, Masjaya, Yusuf S, Ruslim Y, Ma'ruf A. 2020. Fauna diversity, production potential and total economic value of mangrove ecosystems in Mentawir Village, East Kalimantan, Indonesia. Biodiversitas 21 1940-1953.

[30] Siahaya ME, Matius P, Aipassa M.I, Rayadin Y, Ruslim Y, Aponno HSES. 2021. Potential analysis of location, socio-culture and biodiversity as ecotourism attraction in Valentine Bay on Buano Island, West Seram, Maluku, Indonesia. Biodiversitas 22 438-448.

[31] Sulistiyowati. 2017. Directives coastal area development pangempang in muara district Kutai Kartanegara. Thesis. Department Regional Planning Engineering and City Faculty of Science and Technology UIN Alauddin Makassar.

[32] Rozani R. 2017. Regional zoning plan pangempang coast ecotourism development. Post Bachelor of Forestry Science, Faculty Forestry University Mulawarman. Samarinda.

[33] Kristiningrum R, Lahjie AM, Masjaya, Yusuf S, Ruslim Y. 2019. Species diversity, stand productivity, aboveground biomass, and economic value of mangrove ecosystem in Mentawir Village, East Kalimantan, Indonesia. Biodiversitas 20 28482857.

[34] Nikentari N, Ritha N, Haryadi T. 2018. Tide prediction using backpropagation artificial neural network. $J$ of Research and Applied Industry Results 7 1-6.
[35] Chirilă D, Chirilă M, Sîrbulescu C. 2018. Study regarding manifestation forms of sustainable tourism. Scientific Papers: Animal Sci and Biotech 51.

[36] Nalayani H. 2016. Evaluation and Development Strategy for Tourism Villages in Badung Regency, Bali. J of the Master of Tourism 2 189-198.

[37] Mowforth M, Munt I. 2021. Tourism and sustainability. In Tourism and Sustainability.

[38] Dwyer L, Cvelbar LK, Edwards D, Mihalic T. 2012. Fashioning a destination tourism future: The case of Slovenia. Tourism Manage 33 305-316.

[39] Oyola M, Blancas FJ, González M, Caballero R. 2019. Sustainable tourism tags to reward destination management. J of Enviro Manage 250 $109-458$.

[40] Georgudaki J, Kalogeras A, Konstantinopoulos P, Theodoropoulos C. 2016. Sustainable tourism management and development of a Greek coastal municipality. International J of Sustain Dev and World Ecology 23 143-153.

[41] Gulo Y, Sugiharto. 2017. Development of red sand tourism object in Ombolata Village Afulu, Nias District. Tunas Geografi.

[42] Heryati, Y. 2019. Potential for beaching tourism object development Tapandullu in Mamuju District. Scie J of Dev Eco 1 56-74.

[43] Bagri GS, Kala D. 2016. Resident's attitudes toward development and impact in Koti-Kanasar, Indroli, Pattyur Tourism Circuit of Uttarakhand State, India. PASOS Revista de Turismo y Patrimonio Cultural 14 23-39.

[44] Pratomo MB, Sadad A. Efforts to Develop Tourism Objects in the City of Padang. Student Online Journal 3 1-12

[45] Syam, Arif MA. 2017. Development strategy for Sumedang Beach Tourism Objects in Ranah Pesisir District, Pesisir Selatan Regency. J of School Leadership and Manage 2 191-200.

[46] Nastiti CEP, Umilia E. 2013. Marine tourism area development factors in Jember Regency. POMITS Engineering Journal 2 164-167.

[47] Ariani NKD, Suryawan IB. 2019. Planning for the development of the Coastal Tourism Area, Gianyar Regency. J of Tourism Destinations 6258 